\title{
Editorial
}

\section{Talking about Crime, Criminal Law and Criminal Justice in Europe: A Case for More Interdisciplinary Dialogue}

\author{
Estella Baker \\ Professor of European Criminal Law \& Justice, Leicester De Montfort Law \\ School, De Montfort University, United Kingdom \\ ebaker@dmu.ac.uk
}

Back in 1993 the very first issue of this journal was introduced by a foreword that set out the vision and ambitions of the founding editors. ${ }^{1}$ More recently, in 2014, the Editorial Board took steps to reiterate the Journal's mission in an updated form, resulting in the statement of aims and scope that now appears inside the front cover of every issue and on the Journal's website. ${ }^{2}$ Both texts cite the impact of European integration on criminal laws and policies, the growing role of key actors in setting the normative agenda (these days, the European Union and the Council of Europe are those mentioned by name) and a tendency for crimes to exhibit some degree of cross-border character as rationales for the Journal's existence. ${ }^{3}$ They also find common ground in extolling the virtues of the Journal as a forum for interdisciplinary dialogue. Thus, according to the founding editors:

the time had come to provide a real European forum for discussion of criminal policy and legal as well as criminological research in the fields

1 (1993) 1(1) European Journal of Crime, Criminal Law and Criminal Justice 2.

2 https://brill.com/view/journals/eccl/eccl-overview.xml.

3 Each also mentions other factors that reflect the time at which it was drafted, testifying to the way that the field developed during the intervening 20 years. 
concerned and to serve as a major source of information about those issues. $^{4}$

This is an opinion with which the current editors agree. Hence, the statement of aims and scope pronounces that the aim of the Journal is "to offer a multidimensional international and comparative perspective on crime, criminal law and criminal justice in Europe" and solicits papers "from any relevant disciplinary outlook or approach...".

That the Journal affords the opportunity for interdisciplinary exchange is therefore central to its identity and, as a Board, we take seriously the responsibility to ensure that its contents bear out its interdisciplinary mission. In terms of the Journal's overall health, the corollary is that we hope that its multidimensional coverage will attract a similarly diverse readership. Succeeding in this second aim should promote a virtuous circle whereby those who are looking for a forum through which to enter into dialogue across the Journal's disciplinary components (European criminal law or policy; comparative criminal law, policy or practice in European states; analyses of manifestations or representations of crime and/or its impact in Europe; contributions to criminological debate in Europe) will be motivated to submit their work to us.

In order to promote these objectives we are proactive in monitoring the Journal's disciplinary content and the balance that is being achieved between the respective elements. Taking the last two volumes as an example, we are encouraged to have published articles on such diverse topics as: effective remedies in relation to the right to counsel under Directive 2013/48/EU;" "embassy espionage" in Austria and the treatment of espionage under the criminal laws of Austria, Germany and Switzerland; 6 rehabilitation as a positive obligation under the case law of the European Court of Human Rights; ${ }^{7}$ the impact of immigration on crime rates; ${ }^{8}$ and the powers of the Dutch police to fight

4 (1993) 1(1) European Journal of Crime, Criminal Law and Criminal Justice 2.

5 A. Soo, 'Article 12 of Directive 2013/48/EU: A starting point for discussion on a common understanding of the criteria for effective remedies of violation of the right to counsel' (2017) 25(1) European Journal of Crime, Criminal Law and Criminal Justice 31.

6 I. Haider, 'Austrian law as a safe haven for foreign spies? An analysis on the basis of the recent phenomenon of 'embassy espionage' (2018) 26(3) European Journal of Crime, Criminal Law and Criminal Justice 201.

7 S. Meijer, 'Rehabilitation as a positive obligation' (2017) 25(2) European Journal of Crime, Criminal Law and Criminal Justice 145.

8 D. Ignatans and R. Matthews, 'Immigration and the crime drop' (2017) 25(3) European Journal of Crime, Criminal Law and Criminal Justice 205. 
cybercrime. ${ }^{9}$ On the basis of this sample, it appears that the constituencies that we aim to include are finding representation within the Journal's covers.

With notable exceptions, ${ }^{10}$ however, there are rather fewer articles that are interdisciplinary in their own right; that is to say, articles that combine material from across the Journal's disciplinary elements. Given the dominance of disciplinary divides, it can be problematic to place work of this type, but the Journal offers a natural home because of its consciously inclusive ethos. Going further, the purpose of this Editorial is to suggest that there is also substantially untapped potential for contributions within two further interdisciplinary categories to appear in the Journal. They are:

(i) discussions of developments or issues that, on the face of it, fall within the province of one of our composite disciplines from the perspective of one or more of the others; and

(ii) discussions from the perspective of our composite disciplines of the "big" issues that are facing contemporary Europe and their impact upon and/ or relevance to crime, criminal law and criminal justice.

Expanding upon this proposition, each category will be explored with the aid of some illustrative examples.

\section{Category 1: Discussion from Another of the Journal's Disciplinary Perspectives of a Development or Issue that, Prima Facie, "belongs" to One of the others}

Disciplines have an important place in the scheme of things. Among their benefits, they provide a setting for the development of intensities of expertise, together with complementary analytical tools and methodologies, and a means of enquiry into different sorts of questions. Empirically though, the world is not organised according to neat disciplinary dividing lines. In the realm of the natural sciences, this fundamental reality was the theme of an insightful ввС documentary series, called Connections. ${ }^{11}$ Broadcast in the late 1970s, it sought

R.L.D. Pool and B.H.M. Custers, 'The police hack back: Legitimacy, necessity and privacy implications of the next step in fighting cybercrime' (2017) 25(2) European Journal of Crime, Criminal Law and Criminal Justice 123.

$10 \quad$ For example, L. Kazyrytski and A. Sukharenko, 'Russian organised crime in Spain: Its criminal law treatment and some criminological considerations regarding its characteristics and prevalence' (2019) 27(1) European Journal of Crime, Criminal Law and Criminal Justice 6o.

11 An updated book based on the television series is still available: J. Burke, Connections (Simon and Schuster, 2007). 
to illustrate the inherently organic character of scientific development. That is to say that progress and achievement in any given disciplinary sphere is the product of interconnected incremental breakthroughs in others that can be traced back through the long arc of human history.

This is a perspective that has salience beyond the natural sciences. Transferred to the context of the Journal, it provides a valuable prompt that issues or developments that we tend to associate with any one discipline in our mix are liable to have dimensions that derive from, or are relevant to, the others. In principle, therefore, intellectual, and possibly also practical, benefits should accrue from encouraging multi-dimensional discussion of topics that, on the face of it, fit squarely within the sphere of concern of one of our constituent disciplines. Doing so should promote a richer reflection upon the significance and meaning of developments in the field and/or suggest fertile avenues for prospective research and for prospective criminal law and policy development. To expand upon these points, two examples will now be discussed.

\subsection{Joined Cases C-404/15 and C-659/15 PPU Aranyosi and Căldăraru ${ }^{12}$}

As many readers of the Journal will be well aware, the ruling of the Court of Justice of the EU ["CJEU"] in Joined Cases C-404/15 and C-659/15 PPU Aranyosi and Căldăraru concerned the European arrest warrant. Specifically, the Court was requested to clarify the responsibilities of an executing Member State in circumstances where there are strong indications that detention conditions in the issuing Member State are such that they are liable to infringe the fundamental (human) rights of the subject of the warrant. This was a highly contentious issue. The underpinning framework decision provides a restricted set of grounds for refusal to execute, some of which are mandatory and others of which are optional, but infringement of fundamental rights is not included under either heading. ${ }^{13}$ Its omission was known to be a source of concern to national courts ${ }^{14}$ and was a focus of wider criticism of the arrest warrant system.

The response of the Court to the particular type of infringement that was in issue in Aranyosi and Căldăraru was to assert that:

where there is objective, reliable, specific and properly updated evidence with respect to detention conditions in the issuing Member State

\footnotetext{
12 ECLI:EU:C:2016:198.

13 Council framework decision 2002/584/JHA of 13 June 2002 on the European arrest warrant and the surrender procedure between Member States (OJ 2002 L 190/01), Articles 3 and 4.

14 See, for example, Case C-396/11 Radu ECLI:EU:C:2013:39.
} 
that demonstrates that there are deficiencies, which may be systemic or generalised, or which may affect certain groups of people, or which may affect certain places of detention, the executing judicial authority must determine, specifically and precisely, whether there are substantial grounds to believe that the individual concerned by a European arrest warrant, issued for the purposes of conducting a criminal prosecution or executing a custodial sentence, will be exposed, because of the conditions for his detention in the issuing Member State, to a real risk of inhuman or degrading treatment, within the meaning of Article 4 of the Charter [of Fundamental Rights of the EU], in the event of his surrender to that Member State. ${ }^{15}$

And it went on to specify that:

the executing judicial authority must request that supplementary information be provided by the issuing judicial authority, which,..., must send that information within the time limit specified in the request. The executing judicial authority must postpone its decision on the surrender of the individual concerned until it obtains the supplementary information that allows it to discount the existence of such a risk. If the existence of that risk cannot be discounted within a reasonable time, the executing judicial authority must decide whether the surrender procedure should be brought to an end. ${ }^{16}$

Understandably, the ruling has stimulated plenty of discussion among European criminal lawyers, including in this Journal. ${ }^{17}$ Likewise, it has received attention from policy-makers because of its practical implications. ${ }^{18}$ Notwithstanding that the arrest warrant system has problematic aspects, arguably, it has been the most successful of the EU's criminal law initiatives in terms of

15 Joined Cases C-404/15 and C-659/15 PPU Aranyosi and Căldăraru, paragraph 104.

16 Ibid.

17 S. Gáspár-Szilágyi, 'Joined Cases Aranyosi and Căldăraru: Converging human rights standards, mutual trust and a new ground for postponing a European arrest warrant' (2016) 24(2-3) European Journal of Crime, Criminal Law and Criminal Justice 197; J. Ouwerkerk, 'Balancing mutual trust and fundamental rights protection in the context of the European arrest warrant: What role for the gravity of the underlying offence in CJEU case law?' (2018) 26(2) European Journal of Crime, Criminal Law and Criminal Justice 103.

18 See, for example, the discussion of the European Commission's Expert Group on EU Criminal Policy that took place on 23 November 2017: http://ec.europa.eu/transparency/ regexpert/index.cfm?do=groupDetail.groupMeetingDoc\&docid $=8525$. 
securing its aims and the prevalence of its use. ${ }^{19}$ Owing to concerns about the quality of detention conditions in many Member States, however, the decision in Aranyosi had the potential to undermine these achievements, causing the need for careful reflection as to how best to respond. ${ }^{20}$

The issues that the ruling raises are not restricted to these two constituencies though. In principle, for example, it touches upon matters that are of interest to criminologists. Most transparently, this would include those who study prisons and/or who are interested in understanding the concept of imprisonment and its associated pains, but not just them. It would also extend to those with a far broader range of criminological interests, such as the governance of penal power; the impact of economic policy choices (for example, austerity) on penal affairs; and the relevance of the treatment of suspects and offenders to the evolving institution of EU citizenship. Added to these, the judgment establishes an unequivocal premise that decisions to refuse surrender must be based on "objective, reliable, specific and properly updated evidence" regarding detention conditions in the issuing Member State. Criminologists might be expected to have something of value to contribute in determining what this evidence should consist of and how best it should be provided, including the handling of any attendant ethical or other professional implications. These suggestions are not exhaustive but are enough to demonstrate that a ruling such as that in Aranyosi affords ample scope for criminological discussion, and for promoting a deeper, more comprehensive understanding of contemporary developments in European criminal justice.

\subsection{Compliance and Desistance}

One of the striking developments in the criminological field during the last 20 to 30 years has been the emergence of substantial bodies of research into (i) legal compliance and related aspects of political and social capital, such as legitimacy and trust, and (ii) desistance from offending. Much of the impetus has come from a desire to understand such matters as how criminal justice agencies (the police and, more recently, prison officers) maintain order, the

19 In 2016 (the most recent year for which data is complete), 16,636 European arrest warrants were issued and 5,812 were executed: https://e-justice.europa.eu/content_european _arrest_warrant-9o-en.do (last accessed 7 July 2019).

20 The ruling has been followed by other reported cases in which surrender has been refused. In May 2019, for example, a Dutch court refused to surrender a suspected drug smuggler to the UK because of concerns about conditions at HMP Liverpool. See: https:// www.theguardian.com/world/2019/may/10/dutch-court-blocks-extradition-of-man-to -inhumane-uk-prisons?CMP=share_btn_link. 
interaction between substantive and procedural justice, and "what works" in addressing offending behaviour. Curiosity about these kinds of questions has prompted considerable empirical investigation, ${ }^{21}$ the fruits of which are being used to develop a theoretical understanding of the mechanisms that incline individuals towards law abiding behaviour. ${ }^{22}$

Some of this important work, such as the investigation of legitimacy, has already involved interdisciplinary dialogue. ${ }^{23}$ However, the purpose in drawing attention to these areas of criminological scholarship in the context of this editorial is to endorse the view that there is material here that should be of central concern to those who are interested in criminal policy ${ }^{24}$ and also those who are interested in criminal law regulation.

Taking desistance first, a convenient example concerns sentencing policy towards repeat offenders. This is a topic of relevance in all European jurisdictions (and beyond), and which has been the focus of considerable criminological debate. ${ }^{25}$ The parameters of the discussion had been set by the tenets of penal philosophy; the politics of penal policy; perceptions that it is relevant to pay attention to the similarity between new and old offending and the interval between them; and an overarching regard for proportionality. However, as one of the objectives of the sentencing system is to dissuade individuals from reoffending, it makes sense for policy-makers also to take account of the developing knowledge of desistance in determining their approach. In principle, a functional sentencing system should aim to promote the mechanisms of desistance or, at the very least, to ensure that they are not obstructed or undermined. It follows that there might be an evidence based case for treating

21 Some of the relevant work has been published in the Journal. See, for example, S. Egharevba, 'Minority perception of police legitimacy in Finland: The patterns and predictors' (2018) 26(4) European Journal of Crime, Criminal Law and Criminal Justice 282; R. Hacin, 'Prisoners' perceptions of legitimacy of prison staff in Slovenia' (2018) 26(2) European Journal of Crime, Criminal Law and Criminal Justice 160; S. Zdun, 'Accumulated uneasiness - A pathway towards desistance among delinquent youth' (2018) 26(1) European Journal of Crime, Criminal Law and Criminal Justice 40.

22 In relation to legal compliance, see, for example, A.E. Bottoms, 'Morality, crime, compliance and public policy' in A.E. Bottoms and M. Tonry (eds), Ideology, Crime and Criminal Justice: A Symposium in Honour of Sir. Leon Radzinowicz (Willan, 2002).

23 See, for example, J. Tankebe and A. Liebling (eds), Legitimacy and Criminal Justice: An Exploration (Oxford University Press, 2013).

24 See A.E. Bottoms, op. cit., pages 42-45.

25 See, for example, S. Snacken, D. van Zyl Smit and K. Beyens, 'European sentencing practices' in S. Body-Gendrot et al (eds), The Routledge Handbook of European Criminology (Routledge, 2014), page 387 . 
repeat offenders who show signs of desisting from offending differently from those whose offending behaviour appears to be escalating. ${ }^{26}$

Turning to compliance, writing elsewhere, I have utilised the criminologist, Anthony Bottoms', framework of the principal mechanisms that underpin legally compliant behaviour ${ }^{27}$ as a means of analysing the legislative competence under Article $83(2)$ TFEU. ${ }^{28}$ Article $83(2)$ is the provision that permits the EU legislature to adopt directives that "establish minimum rules with regard to the definition of criminal offences and sanctions" in an area that has been subject to harmonisation measures in cases where such measures are "essential to ensure the effective implementation of a [relevant] Union policy". By adopting a compliance approach it was possible to illuminate neglected features of this competence that do not emerge from legal analysis. Added to that, the approach facilitated a discussion of the potential contribution of Article 83(2) to the putative notion of a pan-EU morality and to the achievement of the EU's constitutional project to fashion itself into an Area of Freedom, Security and Justice ["AFSJ"]. It therefore provided a means for obtaining a deeper understanding of Article 83(2).

Mirroring the observations that were made in discussing Aranyosi, these two examples illustrate the potential for those whose primary disciplinary concern lies with European criminal policy and/or criminal law (broadly defined) to examine matters that are of concern to them in the context of advances in the criminological field.

2
Category 2: Discussion from the Perspective of the Journal's Composite Disciplines of the "big" Issues that are Facing Contemporary Europe and their Impact upon and/or Relevance to Crime, Criminal Law and Criminal Justice

In addition to contributions that focus upon particular issues and developments within the field of the Journal, there is room in its pages for "think" pieces that explore urgent problems, new trends and/or seek to address

26 See also E. Baker and A.J. Ashworth, 'The role of previous convictions in England and Wales' in J.V. Roberts and A. von Hirsch (eds), Previous Convictions at Sentencing: Theoretical and Applied Perspectives (Hart, 2010).

27 A.E. Bottoms, op. cit., especially page 30.

28 E. Baker, "A case of "nested enforcement": Article 83(2) TFEU, compliance and the Area of Freedom, Security and Justice post-Lisbon' in S. Drake and M. Smith (eds), New Directions in Effective Enforcement of EU Law (Edward Elgar, 2016). 
research questions that are directed at the macro level as they apply to its sphere of interest. Although not inevitably the case, such contributions are liable to lend themselves to interdisciplinary enquiry because of their nature and scale. Reproducing the approach that was adopted above, two illustrations will now be sketched out.

\subsection{Political Populism ${ }^{29}$}

One contemporary phenomenon within Europe (and beyond) that is attracting attention is the rise of political populism; that is, a politics, of the left or the right, that is characterised by an antagonistic relationship between "the people" and a (corrupt or incompetent) "elite". It is a development that suggests many questions that are worthy of exploration in this Journal.

Most straightforwardly, of course, there is scope for analysis of the policy proposals that are promoted by populist parties as they relate to, or affect, crime, criminal law and internal security. Not only is such analysis relevant in understanding the ideas that are taking root at the national level of European states but there is the linked question of the potential influence of populist thinking upon the criminal policy of the EU. ${ }^{30}$ These are not the only possibilities though.

A further line of enquiry concerns the wider impact of the climate of populism upon the profile and/or incidence of crime. For example, following the EU referendum that took place in the UK in June 2016 there was a spike in the number of hate crime offences that were recorded by the police in England and Wales. ${ }^{31}$ Academic analysis suggests that, while some of the increase can be explained by other factors, the data did reflect a genuine rise in this type of

29 While the ideas in this section are my own, they have been influenced by contributions to the De Montfort University Jean Monnet Centre of Excellence in European Governance Summer School on 'A New Politics of Populism? Democracy in the $21^{\text {st }}$ Century' that took place from 1-4 July 2019. I should like to thank those present for their intellectual stimulation.

30 Under the post-Lisbon treaties the ordinary legislative procedure, in which legislation is adopted by the Council of Ministers acting in conjunction with the European Parliament (Article $294 \mathrm{TFEU}$ ), has become the norm in criminal matters. It carries the potential for populist ideas to surface in either or both of the two Institutions that are involved.

31 A. O'Neill, Hate Crime, England and Wales, 2016/17, Statistical Bulletin 17/17 (Home Office, 17 October 2017), Figure 2.2. Available at: https://assets.publishing.service.gov.uk/government/uploads/system/uploads/attachment_data/file/652136/hate-crime-1617-hosb1717. pdf. 
crime..$^{32}$ Taking the referendum result as a marker of populism, what, if any, is the connection between the two things?

A different set of questions emerges through focusing on the concept of populism itself. According to one interpretation, it can best be understood as a form of political strategy that is designed to mobilise support for the particular policy platform with which it is associated. ${ }^{33}$ Reflecting on the antagonism between "the people" and "the elite" that lies at its heart, it becomes apparent that it has a barely concealed moral overtone. Putting these pieces together, superficially at least, there would appear to be some resonance between populism and certain ideas that are well-known to criminology. One is the concept of the "moral panic" that originated in Stan Cohen's classic study of Mods and Rockers in the 1960 s. $^{34}$ Another might be Jonathan Simon's more recent account of the way in which the figure of the "crime victim" has been mobilised in the US as the idealised political subject of legislation in order to facilitate the use of crime as a governance strategy. ${ }^{35}$ Added to these, over 20 years ago, the eminent British criminologist, Anthony Bottoms, coined the term "populist punitiveness" to describe a particular set of penal policies that were starting to find favour at that time. ${ }^{36}$ All three of these contributions have proved lastingly influential as they have each stimulated other scholars to take up their ideas and integrate them into their research agendas, thereby generating a rich body of further work. Might it contain insights that would be of value in understanding the populist turn that we are currently witnessing?

Another avenue for exploration concerns the aspect of populism that constitutes an attack on elites. Like the notion of "the people", that of "the elite" is ill-defined and heavily dependent upon the accompanying ideology to which populism is attached. Nevertheless, it is without doubt that there are strands

32 D. Devine, The UK Referendum on Membership of the European Union as a Trigger Event for Hate Crimes, 5 February 2018. Available at: https://papers.ssrn.com/sol3/papers. cfm?abstract_id $=3118190$ (last accessed 8 July 2019).

33 Populism has been described as a "thin-centred ideology" because it does not stand on its own, but must be attached to another ideological agenda. See, for example, C. Mudde and C.R. Kaltwasser, Populism: A Very Short Introduction, (Oxford University Press, 2017), page 6 .

34 S. Cohen, Folk Devils and Moral Panics (Routledge Classics), (Routledge, 2011).

35 J. Simon, Governing Through Crime: How the War on Crime Transformed American Democracy and Created a Culture of Fear (Oxford University Press, 2007).

36 A.E. Bottoms, 'The philosophy and politics of punishment and sentencing' in C.M.V. Clarkson and R. Morgan (eds), The Politics of Sentencing Reform (Clarendon Press, 1995), especially pages $39-41$. 
within populism that equate "elite" with "expert". ${ }^{37}$ The advent of this line of thinking heralds a challenge to the established status of the criminal justice professional and threatens the principle that criminal policy should be evidence-based. Therefore, it raises issues that are highly relevant to the Journal.

\subsection{The Nature and Direction of European Criminal Law and Policy}

Almost by definition, many, if not all, contributions to the Journal have something to say about the nature and direction of European criminal law and/or policy, even when that is not a focal aim. To place these matters centre stage and attempt to make sense of the overall pattern of developments is, however, an important task that lies at the heart of the Journal's mission. As well as addressing the empirical question of what law and policy is actually emerging, there is also scope for reflecting on the normative question of what law and policy ought to be emerging. There are also allied matters that deserve investigation, such as how these questions apply specifically to the EU in the context of the AFSJ and whether there is such a thing as a "European brand" of criminal law and justice that can be distinguished from that which is found elsewhere. ${ }^{38}$ All of these issues are susceptible to discussion from the distinct disciplinary vantage points that the Journal is intended to serve and all have a place in the "real European forum" that it was designed to create.

To sum up, the purpose of this editorial has been to draw attention to the potential for a greater degree of interdisciplinary dialogue in the forum that is provided by the Journal. It has done so by sketching out a small number of examples, some of which may have more substance than others. That is not important. If it stimulates the submission to us of an increased volume of interdisciplinary contributions, it will have succeeded in its aim.

37 Illustrated by the infamous comments of the Conservative MP, Michael Gove, during the EU referendum campaign in the UK. During a television interview on 3 June 2016 he asserted that: "People in this country have had enough of experts": https://www.youtube. com/watch?v=GGgiGtJk7MA. Subsequently, during a radio interview on 21 June 2016, he went further and compared economic experts who were warning against Brexit to the Nazis who had smeared Albert Einstein's scientific achievements: https://www.independent.co.uk/news/uk/politics/eu-referendum-brexit-economy-latest-live-what-it-meansmichael-gove-nazis-remain-leave-a7094931.html.

38 See also T. Daems, D. van Zyl Smit and S. Snacken (eds), European Penology?, Oñati International Series in Law and Society (Hart, 2013). 